УДК 332.3

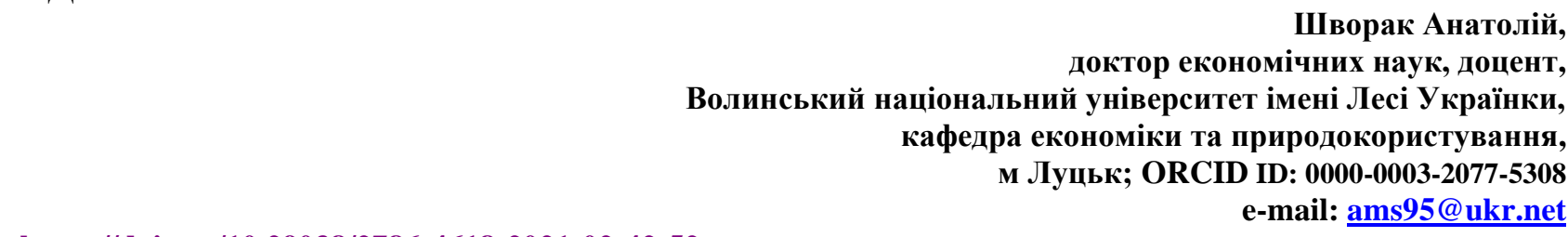

https://doi.org/10.29038/2786-4618-2021-02-42-52

\title{
МЕТОДИЧНІ ПІДХОДИ ДО ФОРМУВАННЯ ЦІНИ НА ЗЕМЛІ СІЛЬСЬКОГОСПОДАРСЬКОГО ПРИЗНАЧЕННЯ
}

\begin{abstract}
Анотація. Рівень ціни на землю сільськогосподарського призначення - запорука ефективного функціонування їх ринку. В статті запропоновані методичні підходи та проведений прогнозований розрахунок рівня цін земель сільськогосподарського призначення в Україні на основі ретроспективного аналізу функціонування ринку земель сільськогосподарського призначення i особливо рівня цін на початку ХX століття, застосовано методичні підходи стосовно вартості землі при вилученні ії з сільськогосподарського обороту, запропоновано методологічний принцип формування ціни землі через капіталізацію величини орендної плати та на окремих економічних показниках : співідношення продукції рослинництва і твариництва, експорту сільськогосподарської продукції 3 1 гектара угідь, заробітної плати працівників сільськогосподарської галузі в порівнянні з країнами Свросоюзу. Проаналізовано динаміку зміни вартості земель в часі.
\end{abstract}

Ключові слова: рілля, ціна землі, землі сільськогосподарського призначення, оренда земель, ціна земель сільськогосподарського призначення, ринок земель сільськогосподарського призначення.

Шворак Анатолий, доктор экономических наук, доцент, Волынский национальный университет имени Леси Украинки, кафедра экономики и природопользования,

г. Луцк

\section{МЕТОДИЧЕСКИЕ ПОДХОДЫ К ФОРМИРОВАНИЮ ЦЕНЫ НА ЗЕМЛИ СЕЛЬСЬКОХОЗЯЙСТВЕННОГО НАЗНАЧЕНИЯ}

\begin{abstract}
Аннотация. Уровень цен земель сельскохозяйственного назначения - залог эффективного функционирования их рынка. В статье предложиено методические подходы, прогнозный расчет уровня цен земель сельскохозяйственного назначения в Украине на основании ретроспективного анализа функционирования рынка земель сельськохозяйственного назначения и особенно уровня цен в начале ХХ столетия, использовались методические подходы относительно стоимости земли при изьятии ее с сельськохозяйственного пользования, предложен методологический прынцып формувания цены земель через капитализацию величины орендной платы та на отдельных економических показателях : сосотношения продукции растеневодства и животноводства, експорту сельськохозяйственой продукции с 1 гектара угодий, зароботной платы работников сельськохозяйственной отрасли в сравнении 3 странами Євросоюза. Проанализовано динамику изменения стоимости земель во времени.
\end{abstract}

Ключевые слова: пашня, цена земли, земли сельськохозяйственного назначения, аренда земель, ринок змель сельськохозяйственного назначения

Shvorak Anatoliy,

Doctor of Economics, Professor,

Lesya Ukrainka Volyn National University,

Department of Economics and Nature Management,

Lutsk

\section{METHODIC APPROACHES TO FORMATION OF PRICE ON LANDS OF AGRICULTURAL PURPOSE}


Annotation. The level of price on lands of agricultural purpose is the condition of efficient functioning of their market.The article proposes methodical approaches and projected calculation of level of price on lands of agricultural purpose in Ukraine on the basis of retrospective analysis of functioning of the market of lands of agricultural purpose and especially the level of prices in the beginning of the XX-th century. Methodical approaches as to the cost of land after its withdrawal from agricultural turnover are applied. Methodological principle of formation of price on land due to capitalization of the value of rent and on some economic indicators are proposed: correlation of crop and livestock products, export of agricultural products from 1 hectar of land, salary of workers in agriculture compared with European Union countries. The dynamics of changes of cost of lands in time is analysed.

Key words: arable land, land price, lands of agricultural purpose, land rent, price on land of agricultural purpose, market of lands of agricultural purpose

Постановка проблеми: Як свідчить досвід проведення аграрних реформ, створення ефективного товаровиробника неможлива без обгрунтування стратегії розвитку АПК формування відповідного організаційного, політичного, правового та соціально-економічного середовища. Однак, не зважаючи на глибину наукових досліджень, ефективне й раціональне використання сільськогосподарських угідь в сучасних умовах господарювання залишається до кінця не вирішеною загальнодержавною проблемою i потребує подальшого опрацювання. Сучасний стан ринкової трансформації сільськогосподарського виробництва обумовлює необхідність невідкладного проведення послідовних макроекономічних реформ. Сталий розвиток сільського господарства України й економіки в цілому неможливий без встановлення реальних цін на землю з урахуванням економічних, екологічних та соціальних факторів. Актуальність цього питання не викликає сумніву, оскільки йдеться про становлення і розвиток повноцінного і прозорого ринку земель.

Мета статті - запропонувати методичні підходи та здійснити прогнозний розрахунок рівня цін земель сільськогосподарського призначення в Україні ще до впровадження ринку земель, здійснити порівняння цих цін із розвинутими країнами світу, висвітлити уже існувавший на початку ХХ ст. вітчизняний досвід функціонування ринку земель сільськогосподарського призначення та особливо рівня цін на них.

Виклад основного матеріалу: Нинішня українська модель земельних відносин тяжіє до неоліберальної моделі, що виявляється в надконцентрації земельних ресурсів, монопольному привласненні земельної ренти, сировинній експлуатації галузі, зростанні рівня сільського безробіття, трудовій еміграції, структурних коливаннях на користь високомаржинальних видів продукції рослинництва, виснаженні грунтового покриву, самоусуненні частини вертикально інтегрованих агроформувань від розв'язання соціально-економічних та екологічних проблем територіальних громад тощо. Усе це має істотні негативні наслідки уже сьогодні i значною мірою поглиблюватиметься у майбутньому. Така ситуація вимагає перегляду наявних форм і методів до регулювання економіки, оскільки в країнах, що розвиваються, неоліберальні доктрини не спроможні забезпечити збалансований еко-соціо-економічний розвиток [4].

Із запровадженням ринку землі з 1липня 2021року в Україні вартість визначатиме статистика фактичних продажів та попит і пропозиція. Проте у формуванні ціни на землю можлива досить активна регуляторна політика 3 боку держави. Найпоширеніші регуляторні інструменти які використовуються для регулювання ринкового обігу такі:

-регулювання цін;

-переважне право придбання земельної ділянки;

- максимальні розміри (концентрація земель однією особою);

- кваліфікаційні вимоги до покупців;

- встановлення обмежень відносно відносно покупців (юридичні особи, іноземці);

- обмеження використання земель, тощо.

За умов прийняття стратегії розвитку фермерства в Україні, що є, на нашу думку, найбільш виправдано i купівля земель сільськогосподарського призначення передбачатиметься особами 3 українським громадянством, які проживають, або проживатимуть, i здійснюватимуть свою діяльність в межах територіальної одиниці, де розташована їх земля. Саме за таких умов власник землі буде найбільш зацікавлений у підвищенні добробуту відповідної громади, сільських територій, 
забезпеченні екологічної безпеки, вирішенні соціальних проблем населення тощо. Однак слід зауважити, що в нинішніх умовах в Україні за низької платоспроможності потенціальних покупців в межах територіальної сільської громади ціна на землю, на жаль, буде найнижчою. Мало того, навіть покупець землі конкретної громади, купивши землю, при своїх обмежених коштах, як кажуть, здійснивши купівлю за останні гроші, зменшує свої можливості для інвестицій в своє виробництво, а продавець, отримавши кошти за землю, вилучає їх з сільськогосподарського виробництва громади. Отже, загальна сума активних коштів у сільськогосподарському обігу цієї громади зменшуватиметься. За умови надання права на купівлю земель сільськогосподарського призначення всім особам з українським громадянством, які не обов'язково проживають і проживатимуть в межах територіальної громади ціна на землю буде вища порівняно із першим варіантом, оскільки збільшуватиметься кількість платоспроможних покупців. Натомість під загрозу потрапляс розвиток фермерства. Потенціальний покупець буде менше опікуватися екологічними та соціальними проблемами території, де розташовано його земельну ділянку.

У зв'язку з цим пропонується розглянути декілька методичних підходів визначення ціни землі.

Перший. В Україні лише за останні півтора століття відбулися глибинні соціально-психологічні та економічні трансформації від існування вільного ринку землі наприкінці XIX - на початку XX ст. до державної власності на землю за часів колишнього Радянського Союзу. I нині знову країна стоїть на етапі переходу до ринку землі. У зв'язку із цим на особливу увагу заслуговує власний досвід України на початку $\mathrm{XX}$ ст. щодо функціонування ринку землі, ролі у цьому процесі відповідних земельних банків та надання ними позики на купівлю землі, рівень цін на землю, умови застави тощо. Слід зазначити, що купівля українських земель відбувалася через Селянський поземельний та державний банки. В працях Академіка С.Г.Струміліна зазначено, що в Росії до 1917року вартість гектара сільськогосподарських земель дорівнювала 120 поденним платам сільськогосподарського працівника. Середні покупні ціни у розрізі губерній на території України за 1901 - 1915 рр. ( крб. за десятину) приведені в таблиці 1.

Таблиия 1

Середні покупні ціни у розрізі губерній на території України за 1901 - 1915 рр. ( крб. за десятину)

\begin{tabular}{|l|c|c|c|c|c|c|c|c|}
\hline Губернії & $\begin{array}{c}1901- \\
1905\end{array}$ & $\begin{array}{c}1906- \\
1910\end{array}$ & 1910 & 1911 & 1912 & 1913 & 1914 & 1915 \\
\hline Харківська & 151 & 224 & 243 & 240 & 283 & 307 & 337 & 354 \\
\hline Чернігівська & 139 & 170 & 162 & 166 & 175 & 184 & 187 & 194 \\
\hline Полтавська & 208 & 257 & 275 & 297 & 330 & 332 & 415 & 406 \\
\hline Херсонська & 168 & 216 & 226 & 231 & 236 & 286 & 365 & 415 \\
\hline Катеринославська & 155 & 189 & 211 & 209 & 222 & 304 & 237 & 369 \\
\hline Донська обл. & 104 & 150 & 139 & 161 & 186 & 217 & 177 & 232 \\
\hline Подільська & 188 & 255 & 280 & 304 & 331 & 369 & 419 & 437 \\
\hline Київська & 167 & 226 & 229 & 230 & 237 & 203 & 272 & 284 \\
\hline Волинська & 124 & 168 & 186 & 168 & 176 & 166 & 187 & 209 \\
\hline
\end{tabular}

Слід звернути увагу на досвід функціонування економічного механізму надання землі в заставу за ринку в Україні в 1907- 1911 рр. Аналіз на прикладі Київської губернії свідчить, що ціна продажу 1 га становила тоді 210 руб, при цьому оцінка 1 га закладеної землі в банку сягала вже 126 руб, розмір позики під закладену землю становив 81 руб, або 64 \% від оціночної вартості землі, або лише 39 \% від ринкової ціни землі. Натомість 48-82 \% землі, яка знаходилася в приватній особистій власності, було закладено і перезакладено під заставу [6].

На це потрібно зосередити особливу увагу тому, що подібне співвідношення між ринковою ціною і розміром застави може мати місце і на даний час. Сьогодні царську десятку вага якої становить 7,74 грами чистого золота, яка не має нумізматичної цінності, можна придбати за 400доларів. Вартість чистого золота даної монети по курсу НБУ становить 12000 гривень, або 430 доларів. Розрахунок вартості землі в Україні на даний час наведений в таблиці 2. 
РОЗДІЛ І. Економіка. 2, 2021

Розрахунок вартості землі в Україні на даний час

\begin{tabular}{|c|c|c|c|c|}
\hline \multicolumn{2}{|l|}{ Губернї } & Станом на1915p & Вартість 1га 1915p & Вартість 1га/дол \\
\hline \multicolumn{2}{|c|}{ Харківська } & 354 & 324 & 12960 \\
\hline \multicolumn{2}{|c|}{ Чернігівська } & 194 & 178 & 7120 \\
\hline \multicolumn{2}{|c|}{ Полтавська } & 406 & 372 & 14880 \\
\hline \multicolumn{2}{|l|}{ Херсонська } & 415 & 380 & 15200 \\
\hline \multicolumn{2}{|c|}{ Катеринославська } & 369 & 338 & 13520 \\
\hline \multicolumn{2}{|c|}{ Донська обл. } & 232 & 212 & 8480 \\
\hline \multicolumn{2}{|c|}{ Подільська } & 437 & 400 & 16000 \\
\hline \multicolumn{2}{|l|}{ Київська } & 184 & 168 & 6720 \\
\hline \multicolumn{2}{|l|}{ Волинська } & 209 & 191 & 7640 \\
\hline \multirow[t]{3}{*}{ По Україні } & середня & 311 & 285 & 11391 \\
\hline & Min & Min184 & Min168 & Min 6720 \\
\hline & Mas & Mas437 & Mas400 & Mas16000 \\
\hline
\end{tabular}

Аналізуючи наведені дані, ми бачимо що вартість землі в ринкових умовах за 15 років зросла приблизно в два рази і становила в еквіваленті на сучасні ціни від 6720 до 16000 доларів. Враховуючи , що на даному етапі ринок землі бере свій старт то можна припустити що вартість буде знаходитися в діапазоні від 3000-8000доларів, але на вартість буде впливати якість, місце розташування та попит і пропозиція.

Другий. Слід відзначити, що І. І. Лукінов ще за радянських часів (наприкінці 60-х на початку 70-х років ХХ ст.), коли про ціну землі не могло бути мови, пропонував методичні підходи стосовно вартості землі при вилученні ऑї з сільськогосподарського обороту, зумовлену необхідністю різних видів будівництва тощо. Вартість землі визначалася розміром необхідних відшкодувань сільськогосподарським підприємствам, які еквівалентні витратам, необхідним для відновлення землі гіршої якості до якості вилучених [7]. Нормативи втрат сільськогосподарського виробництва, які підлягають відшкодуванню та розрахунок вартості ріллі наведені в таблиці 3.

Таблицяя 3

Нормативи втрат сільськогосподарського виробництва, які підлягають відшкодуванню (тис. грн. за 1 га)

\begin{tabular}{|l|c|c|}
\hline Регіон & Рілля & Вартіть 1га/дол \\
\hline АР Крим & 96,59 & 3450 \\
\hline Вінницька & 108,25 & 3866 \\
\hline Волинська & 110,64 & 3951 \\
\hline Дніпропетровська & 82,87 & 2960 \\
\hline Донецька & 91,04 & 3251 \\
\hline Житомирська & 80,8 & 2886 \\
\hline Закарпатська & 135,58 & 4842 \\
\hline Запорізька & 69,37 & 2478 \\
\hline Івано-Франківська & 111,19 & 3971 \\
\hline Київська & 116,74 & 4169 \\
\hline Кіровоградська & 82 & 2928 \\
\hline Луганська & 65,89 & 2353 \\
\hline Львівська & 109,55 & 3912 \\
\hline Миколаївська & 65,78 & 2349 \\
\hline Одеська & 75,36 & 2691 \\
\hline Полтавська & 95,4 & 3407 \\
\hline Рівненська & 121,1 & 4325 \\
\hline Сумська & 97,47 & 3481 \\
\hline Тернопільська & 124,58 & 4449 \\
\hline
\end{tabular}


Економічний часопис Волинського національного університету імені Лесі Украӥнки

\begin{tabular}{|l|c|c|}
\hline Харківська & 86,25 & 3080 \\
\hline Херсонська & 77,43 & 2765 \\
\hline Хмельницька & 107,92 & 3854 \\
\hline Черкаська & 122,95 & 4391 \\
\hline Чернівецька & 139,94 & 3998 \\
\hline Чернігівська & 93,33 & 333 \\
\hline
\end{tabular}

Джерело: Постанова К М У від 17 листопада 1997 р. N 1279

Вартість земель згідно даного методу знаходитися в діапзоні 2353 - 4998 доларів за гектар.

За своєю економічною сутністю, відшкодування втрат сільськогосподарського та лісогосподарського виробництва є економічним інструментом регулювання урбанізаційних процесів, що покликаний знизити рентабельність трансформації сільськогосподарських угідь, лісових земель та чагарників у інші угіддя та сприяти залученню інших земель до містобудівних та промислових потреб. Розмір втрат сільськогосподарського і лісогосподарського виробництва, які підлягають відшкодуванню регулюється Земельним Кодексом [1], та встановлюється у порядку, що визначений постановою Кабінету Міністрів України від 17.11.1997 № 1279 [6]. 3 часу прийняття постанови минуло 24 роки і вони до цього часу не індексувалися.

Третій грунтується на теоретичній основі про безпосередній зв'язок між орендною платою і ціною землі. У світовій практиці є варіант визначення ціни землі через капіталізацію орендної плати діленням їі величини на дисконтну ставку. Рівень дисконтної ставки в розвинених країнах світу коливається в межах 1-5 \% і залежить від процентної ставки за користування капіталом. В даному випадку методологічний принцип формування ціни землі через капіталізацію величини орендної плати залишається більш прийнятним. Власник земельної ділянки капіталізацію орендної плати буде здійсноати в розмірі процентної ставки за зберігання готівкових коштів на депозитному рахунку. Про зв’ язок цих величин зазначав В. Петті у праці «Економічні і статистичні роботи» в 1664 р. Отже, формула обчислення ціни землі за цим методичним підходом має вигляд:

Оп

$$
\text { Цзд= -----------х100, де }
$$

Дс

Цзд-ціна земельно ділянки;

Оп-орендна плата;

Дс- депозитна ставка

Даний метод є простим у розрахунку. Розрахунок на основі викладеного підхіду наведено в таблиці 4.

Таблиця 4

Розрахунок вартості земель на основі оренндної плати

\begin{tabular}{|l|c|c|c|c|}
\hline \multirow{2}{*}{ Регіони } & \multicolumn{2}{|c|}{ Орендна плата за 1га с/г землі } & \multicolumn{2}{c|}{ Вартість 1га с/г землі,грн./дол } \\
\cline { 2 - 5 } & $\begin{array}{c}\text { Державної } \\
\text { власності }\end{array}$ & $\begin{array}{c}\text { Приватної } \\
\text { власності }\end{array}$ & $\begin{array}{c}\text { Державної } \\
\text { власності }\end{array}$ & $\begin{array}{c}\text { Приватної } \\
\text { власності }\end{array}$ \\
\hline АР Крим & - & - & & $27075 / 860$ \\
\hline Вінницька & 7137 & 2166 & $79300 / 2832$ & $12967 / 463$ \\
\hline Волинська & 1442 & 1167 & $16022 / 572$ & $14178 / 506$ \\
\hline Дніпропетровська & 2122 & 1276 & $23577 / 842$ & $10511 / 375$ \\
\hline Донецька & 1638 & 946 & $18200 / 650$ & $18744 / 669$ \\
\hline Житомирська & 3030 & 1687 & $33667 / 1202$ & $10344 / 369$ \\
\hline Закарпатська & 1652 & 931 & $18355 / 656$ & $9755 / 348$ \\
\hline Запорізька & 2633 & 878 & $29255 / 1045$ & $15167 / 542$ \\
\hline Івано-Франківська & 3817 & 1365 & $42411 / 1514$ & $20300 / 725$ \\
\hline Київська & 3537 & 1827 & $39300 / 1404$ & $15800 / 564$ \\
\hline Кіровоградська & 4993 & 1422 & $55478 / 1981$ & $11233 / 401$ \\
\hline Луганська & 2905 & 1011 & $32278 / 1153$ & $19156 / 684$ \\
\hline Львівська & 2953 & 1724 & $32811 / 1172$ & $11956 / 427$ \\
\hline Миколаївська & 2769 & 1076 & $30767 / 1099$ & \\
\hline
\end{tabular}


РОЗДІЛ І. Економіка. 2, 2021

\begin{tabular}{|l|c|c|c|c|}
\hline Одеська & 4345 & 1497 & $48278 / 1724$ & $16633 / 594$ \\
\hline Полтавська & 6627 & 2970 & $73633 / 2630$ & $33000 / 1179$ \\
\hline Рівненська & 2625 & 1689 & $29167 / 1042$ & $18767 / 670$ \\
\hline Сумська & 2317 & 1920 & $25744 / 919$ & $21333 / 762$ \\
\hline Тернопільська & 4182 & 1465 & $46467 / 1659$ & $16277 / 581$ \\
\hline Харківська & 3438 & 2495 & $38200 / 1364$ & $27222 / 990$ \\
\hline Херсонська & 1402 & 927 & $15578 / 556$ & $10300 / 368$ \\
\hline Хмельницька & 7781 & 2267 & $86455 / 3088$ & $25189 / 900$ \\
\hline Черкаська & 3723 & 3525 & $41367 / 1477$ & $39167 / 1399$ \\
\hline Чернівецька & 3973 & 1364 & $44144 / 1577$ & $15156 / 541$ \\
\hline Чернігівська & 2600 & 1128 & $28889 / 1032$ & $12533 / 448$ \\
\hline По Україні & 3431 & 1613 & $38122 / 1362$ & $17922 / 640$ \\
\hline
\end{tabular}

Джерело: розрахунки автора за даними Держгеокадастру.

Аналізуючи дані наведені в таблиці ми бачимо суттєву різницю в орендній платі за землі державної і комунальної власності і приватними землями. Вона заключається в тому, що землі державної і комунальної власності були надані на аукціоні, власники земельних паїв здавали свою землю оренду на безальтернативній основі. Вартість земель державної і комунальної власності беде становити від 556 до 3088 доларів і приватних земель 348 - 1399 доларів. Тому агрохолдинги не зацікавлені в законодавчих змінах і всіляко перешкоджають прийняттю нормативних актів які були б направлені на захист інтересів власників часток (паїв).

Четвертий, базується на окремих економічних показниках. Розглянемо такий ключовий показник результативності сільського господарства - експорту сільськогосподарської продукції та продуктів його переробки в розрахунку на 1 га земель. Найбільш привабливими для логічного розуміння ціни землі в таблиці $1 €$ показники експорту сільськогосподарської продукції та ринкової ціни 1 га ріллі в країнах Євросоюзу (табл. 5). Тобто, між величинами ціни землі і експорту сільськогосподарської продукції простежується практично пряма залежність: чим вищий рівень експорту з одиниці площі ріллі, то прямо пропорційно вища ії ціна. Порівняння з будь-якою країною, які перевищують Україну за показником експорту в розрахунку на 1 га ріллі (таких 123 країни у світі), показує таку ж залежність ціни землі від обсягу експорту сільськогосподарської продукції. Останнє в першу чергу залежить від структури посівних площ та щільності поголів'я тварин у розрахунку на 1 га ріллі. Що більше тварин і птиці на 1 га ріллі (Україна на 185 місці серед 206 країн) та що більше посівні площі насичені високодохідними культурами, то вища ціна землі. Це аксіома. Ціна також може дуже зрости, якщо в середовищі наростаючого дефіциту сільськогосподарської землі в більшості країн світу до ринку української землі будуть залучені іноземні інвестори.

Відзначимо, що саме фермерські господарства розміром до 200 га, які $\epsilon$ в Європі, запроваджують набір високоінтенсивних виробництв й відповідно високодохідних, що не можуть собі застосувати підприємства фізичним розміром більш ніж 10 тис. га ріллі. Саме це дає можливість дрібнішим господарствам у десятки, а то і в сотні разів більше експортувати 31 га ріллі, ніж великі підприємства зерново-соняшникової спеціалізації.

Розрахунок вартості 1га с/г земель на основі екпортного потенціалу

\begin{tabular}{|l|l|c|c|c|c|c|c|}
\hline $\begin{array}{l}\text { № } \\
\Pi \Pi\end{array}$ & $\begin{array}{c}\text { Країна } \\
\text { Площа } \\
\text { земель, } \\
\text { тис.га }\end{array}$ & $\begin{array}{c}\text { У } \\
\text { влас- } \\
\text { ності, } \\
\%\end{array}$ & $\begin{array}{c}\text { Співвідношення } \\
\text { продукції } \\
\text { рослинництва і } \\
\text { тваринництва }\end{array}$ & $\begin{array}{c}\text { Вартість } \\
\text { 1га, } \\
\text { тис. } \\
\text { євро }\end{array}$ & $\begin{array}{c}\text { Екс } \\
\text { порт } \\
\text { 3 1га, } \\
\text { євро }\end{array}$ & $\begin{array}{c}\text { Окупність } \\
\text { років, по } \\
\text { екс- } \\
\text { порту }\end{array}$ \\
\hline 1 & Нідерланди & 2730 & 89 & $56,4 / 43,6$ & 63,7 & 12088 & 5,2 \\
\hline 2 & Австрія & 2880 & 53 & $49,5 / 50,5$ & 42,0 & 3882 & 10,8 \\
\hline 3 & Німеччина & 16700 & 49 & $51,7 / 48,3$ & 32,3 & 4585 & 7,4 \\
\hline 4 & Італія & 12850 & - & $63,2 / 36,8$ & 40,0 & 3214 & 12,4 \\
\hline 5 & Іпанія & 23850 & 70 & $63,5 / 36,5$ & 16,1 & 1967 & 16,1 \\
\hline 6 & Греція & 3470 & 60 & - & 11,0 & 1726 & 6,4 \\
\hline
\end{tabular}


Економічний часопис Волинського національного університету імені Лесі Украӥнки

\begin{tabular}{|l|l|c|c|c|c|c|c|}
\hline 7 & Польща & 14440 & 81 & $48,8 / 51,2$ & 10,3 & 2281 & 4,5 \\
\hline 8 & Франція & 27850 & 80 & $60,7 / 39,3$ & 7,4 & 2435 & 3,4 \\
\hline 9 & Естонія & 940 & 56 & - & 5,0 & 843 & 5,9 \\
\hline 10 & Болгарія & 3600 & 98 & $62,5 / 37,5$ & 4,6 & 1170 & 3,9 \\
\hline & Середнє & - & - & - & 2683 & & 7,6 \\
\hline 11 & Україна & 41329 & 81 & $74,5 / 25,5$ & & 353 & \\
& min & & & & 1200 & & 3.4 \\
& таs & & & & 5683 & & 16.1 \\
\hline
\end{tabular}

Джерело: розрахунки автора за даними Євростату та Держкомстату України.

Наведені в таблиці розрахунки відображають, що вартість землі буде в існуючій економічній ситуації знаходитися в межах 1200 з перспективою росту в часі при зміні структури експортного потенціалу до 5683 долара.

Пятий метод відображає як вартість землі залежить від середньомісячної заробітної плати працівників сільського господарства в країнах Євросоюзу.

Між величинами зарплати i виробництвом сільськогосподарської продукції та глибиною переробки та іiі експорту с простежується практично пряма залежність: чим вищий рівень експорту 3 одиниці площі ріллі, то прямо пропорційно вища їі ціна.

Наведені в таблиці 6 розрахунки відображають, що вартість землі буде в існуючій економічній ситуації знаходитися в межах від 1001 з перспективою росту в часі при зміні структури виробництва та експортного потенціалу до 6755 доларів.

Кожна країна у той чи інший спосіб регулює ринковий обіг земель, виходячи 3 конкретних особливостей та національних інтересів. Саме на державу покладаються функції щодо забезпечення відповідності функціонування та спрямування ринкового обігу земель обраній моделі такого обігу. Крім того, особливої уваги з боку держави потребує обіг земель саме на початковому етапі становлення. Зважаючи на це, відповідь на питання стосовно необхідності державного регулювання ринкового обігу земель сільськогосподарського призначення очевидна - ринковий обіг земель сільськогосподарського призначення має бути регульований державою.

Таблиия 6

Розрахунок вартості 1га с/г земель на основі на основі заробітної плати працівників сільського господарства

\begin{tabular}{|c|c|c|c|c|c|c|c|c|}
\hline $\begin{array}{l}\text { № } \\
\Pi \backslash \Pi\end{array}$ & Країна & $\begin{array}{c}\text { Площа } \\
\text { с } Г \\
\text { земель, } \\
\text { тис.га }\end{array}$ & $\begin{array}{c}\text { У } \\
\text { влас- } \\
\text { ності, } \\
\%\end{array}$ & $\begin{array}{c}\text { Співвідношення } \\
\text { продукції } \\
\text { рослинництва і } \\
\text { тваринництва }\end{array}$ & $\begin{array}{l}\text { Варті } \\
\text { сть } \\
1 г а, \\
\text { тис. } \\
\text { євро }\end{array}$ & $\begin{array}{l}\text { Екс } \\
\text { порт } \\
31 \text { 1га, } \\
\text { євро }\end{array}$ & $\begin{array}{c}\text { Середня } \\
\text { заробітна } \\
\text { плата, } \\
\text { євро/ } \\
\text { місяць }\end{array}$ & $\begin{array}{c}\text { За } \\
\text { скільки } \\
\text { місяців } \\
\text { роботи } \\
\text { можна } \\
\text { купити } \\
\text { 1га }\end{array}$ \\
\hline 1 & Нідерланди & 2730 & 89 & $56,4 / 43,6$ & 63,7 & 12088 & 3975 & 16,0 \\
\hline 2 & Австрія & 2880 & 53 & $49,5 / 50,5$ & 42,0 & 3882 & 2768 & 15,1 \\
\hline 3 & Німеччина & 16700 & 49 & $51,7 / 48,3$ & 32,3 & 4585 & 4021 & 8,0 \\
\hline 4 & Італія & 12850 & - & $63,2 / 36,8$ & 40,0 & 3214 & 2467 & 16,2 \\
\hline 5 & Іпанія & 23850 & 70 & $63,5 / 36,5$ & 16,1 & 1967 & 1890 & 8,5 \\
\hline 6 & Греція & 3470 & 60 & - & 11,0 & 1726 & 1588 & 6,9 \\
\hline 7 & Польща & 14440 & 81 & $48,8 / 51,2$ & 10,3 & 2281 & 1124 & 9,2 \\
\hline 8 & Франція & 27850 & 80 & $60,7 / 39,3$ & 7,4 & 2435 & 3084 & 2,4 \\
\hline 9 & Естонія & 940 & 56 & - & 5,0 & 843 & 1433 & 3,5 \\
\hline 10 & Болгарія & 3600 & 98 & $62,5 / 37,5$ & 4,6 & 1170 & 693 & 6,6 \\
\hline & Середнє & - & - & - & & & - & 9,24 \\
\hline 11 & $\begin{array}{l}\text { Україна } \\
\text { min } \\
\text { mas }\end{array}$ & 41329 & 81 & $74,5 / 25,5$ & $\begin{array}{l}2683 \\
1200 \\
5683\end{array}$ & 353 & 417 & $\begin{array}{l}3853 \\
1001 \\
6755\end{array}$ \\
\hline
\end{tabular}

Джерело: розрахунки автора за даними Євростату та Держкомстату України. 
Земельні агентства 3 управління ринковим обігом земель сільськогосподарського призначення країн світу відображені в таблиці 7.

Земельні агентства які регулюють ринок земель сільськогосподарського призначення в країнах світу

\begin{tabular}{|l|l|}
\hline Країна & Земельне агентство \\
\hline Ізраїль & ILA - Israel Land Authority[8] \\
\hline Німеччина & BVVG - Bodenverwertungs- und -verwaltungs GmbH [9] \\
\hline Польща & KOWR - National Center for Agricultural Support [10] \\
\hline Румунія & ADS - The State Domain Agency [11] \\
\hline США & U.S. Department of Agriculture [12] \\
\hline Угорщина & LLC - Local Land Committee [13] \\
\hline Чехія & SPU - State Land Office [14] \\
\hline Франція & SAFER - Land Development and Rural Settlement Society [15] \\
\hline Японія & AC - Agricultural Committee [16] \\
\hline
\end{tabular}

Для того щоб з зпрогнозувати як буде розвиватися ринок земель в Україні проаналізовано зміну ціни на землю після відкриття ринку земель в постсоціалістичних країнах Європи (табл. 8).

Аналіз динаміки ціни землі в постсоціалістичних країнах свідчить, що відбувається суттєве зростання ціни землі.

Таблиия 8

Динаміка цін на землю в країнах Європи після відкриття ринку землі, є/га

\begin{tabular}{|c|c|c|c|c|c|c|c|c|c|c|c|c|c|}
\hline \multirow[t]{2}{*}{ Країна } & \multicolumn{12}{|c|}{$\begin{array}{l}\text { Динаміка цін на землю в країнах Європи після відкриття ринку землі, } \\
\epsilon / \text { га (роки з початку лібералізації) }\end{array}$} & \multirow[t]{2}{*}{ Ріст, $\%$} \\
\hline & Початок & 1 & 2 & 3 & 4 & 5 & 6 & 7 & 8 & 9 & 10 & 11 & \\
\hline Болгарія & 1150 & 1202 & 1595 & 1519 & 1420 & 2092 & 2820 & 2930 & 3832 & 4558 & & & $396 / 44$ \\
\hline \multicolumn{2}{|c|}{$\begin{array}{l}\text { Динаміка до попе- } \\
\text { реднього року,\% }\end{array}$} & 5 & 33 & -5 & $\begin{array}{l}-7 \\
\end{array}$ & 47 & 35 & 4 & 31 & 19 & & & \\
\hline Естонія & 282 & 583 & 894 & 1125 & 1056 & 1111 & 1111 & 1083 & 1333 & 1681 & 2111 & 2417 & $857 / 78$ \\
\hline \multicolumn{2}{|c|}{$\begin{array}{l}\text { Динаміка до попе- } \\
\text { реднього року,\% }\end{array}$} & 107 & 53 & 26 & -6 & 5 & - & -3 & 23 & 26 & 26 & 14 & \\
\hline Латвія & 526 & 1001 & 2183 & 3786 & 3552 & 1940 & 1015 & 1503 & 1804 & 3287 & 4144 & 4818 & $916 / 83$ \\
\hline \multicolumn{2}{|c|}{$\begin{array}{l}\text { Динаміка до попе- } \\
\text { реднього року,\% }\end{array}$} & 90 & 118 & 73 & -6 & -45 & -48 & 48 & 20 & 82 & 26 & 16 & \\
\hline Литва & \begin{tabular}{|l|}
390 \\
\end{tabular} & 406 & 536 & 734 & 831 & 1075 & 971 & 1138 & 1605 & 1608 & 1883 & 2220 & $569 / 51$ \\
\hline \multicolumn{2}{|c|}{$\begin{array}{l}\text { Динаміка до попе- } \\
\text { реднього року,\% }\end{array}$} & 4 & 32 & 37 & 13 & 29 & -10 & 17 & 41 & - & 17 & 18 & \\
\hline Польща & 1310 & 1464 & 2051 & 2388 & 3210 & 3668 & 4083 & 4333 & 4833 & 6150 & 6333 & & $483 / 48$ \\
\hline \multicolumn{2}{|c|}{$\begin{array}{l}\text { Динаміка до попе- } \\
\text { реднього року,\% }\end{array}$} & 12 & 40 & 16 & 34 & 14 & 11 & 6 & 12 & 27 & 3 & & \\
\hline Румунія & 1000 & 972 & 1408 & 1500 & 1727 & 1891 & 2181 & 3000 & 3182 & 3364 & & & $336 / 37$ \\
\hline \multicolumn{2}{|c|}{$\begin{array}{l}\text { Динаміка до попе- } \\
\text { реднього року,\% }\end{array}$} & -3 & 45 & 7 & 15 & 9 & 15 & 37 & 6 & 6 & & & \\
\hline Словатчина & 912 & 946 & 981 & 1017 & 1121 & 1211 & 1256 & & & & & & $138 / 23$ \\
\hline \multicolumn{2}{|c|}{$\begin{array}{l}\text { Динаміка до попе- } \\
\text { реднього року,\% }\end{array}$} & 4 & 4 & 4 & 10 & 8 & 4 & & & & & & \\
\hline Угорщина & 1741 & 1771 & 1853 & 1927 & 1987 & 2221 & 2403 & 2416 & 2544 & 2880 & 3216 & & $185 / 18$ \\
\hline \multicolumn{2}{|c|}{$\begin{array}{l}\text { Динаміка до попе- } \\
\text { реднього року,\% }\end{array}$} & 2 & 5 & 4 & 3 & 12 & 8 & 1 & 5 & 13 & 12 & & \\
\hline Чехія & 1522 & 1561 & 1621 & 1625 & 1867 & 2375 & 2557 & 2807 & 2962 & 3253 & 3400 & 4455 & \\
\hline \multicolumn{2}{|c|}{$\begin{array}{l}\text { Динаміка до попе- } \\
\text { реднього року,\% }\end{array}$} & 3 & 4 & 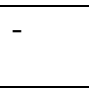 & 15 & 27 & 8 & 10 & 6 & 10 & 5 & 31 & $293 / 27$ \\
\hline
\end{tabular}

Джерело: IMF group of Ukraine та розрахунки автора

Основним фактором встановлення вартості землі на ринку є пропозиція та попит. В таблиці 9 приведено дослідження « Інституту аграрної економіки» НААН. 
Наміри після запровадження ринку землі

Таблиия 9

\begin{tabular}{|c|c|c|}
\hline $\begin{array}{c}\text { Власники які отримали } \\
\text { земельний пай в спадок }\end{array}$ & $\begin{array}{c}\text { Наміри після запровадження } \\
\text { ринку землі }\end{array}$ & $\begin{array}{c}\text { Власники які отримали земельний } \\
\text { пай за місцем роботи }\end{array}$ \\
\hline 38 & Передати в оренду & 48 \\
\hline 7 & Започаткувати ФГ & 3 \\
\hline 15 & $\begin{array}{c}\text { Залишити у використання в } \\
\text { своєму ОСГ }\end{array}$ & 30 \\
\hline 20 & Передати в спадок & 2 \\
\hline 2 & Подарувати & 1 \\
\hline 13 & Продати & 1 \\
\hline 2 & Змінити цільове призначення & \\
\hline
\end{tabular}

Джерело: дослідження « Інституту аграрної економіки» НААН 01.01.2018

Аналізуючи дані даного дослідження, можна передбачити що на ринку з'явиться приблизно 0,6 млн часток (паїв) загальною площею 2,4 млн.га.

Враховуючи наведені метотоди розрахунку вартості землі та соціологічні дослідження в таблиці 10 проведемо порівняння вигоди, отриманої власником земельного паю 31 га у разі його продажу та передачі в оренду.

Таблиия 10

Порівняльна таблиця вигоди при продажі або передачі в оренду земельного паю

\begin{tabular}{|c|c|c|c|c|}
\hline \multirow{2}{*}{ Термін, рік } & \multicolumn{2}{|c|}{ Оренда земельного паю } & \multicolumn{2}{c|}{ Продаж земельного паю } \\
\cline { 2 - 5 } & Вартість оренди & Зростання ціни & Ватртість продажу & Відсоток по депозиту \\
\hline 1 & 1613 & 27520 & 27520 & 2201 \\
\hline 2 & 1613 & 36051 & 29712 & 2377 \\
\hline 3 & 2201 & 47227 & 32089 & 2567 \\
\hline 4 & 2201 & 61867 & 34656 & 2079 \\
\hline 5 & 2201 & 81046 & 36735 & 2204 \\
\hline 6 & 2201 & 106170 & 38939 & 2336 \\
\hline 7 & 2201 & 139083 & 41275 & 1750 \\
\hline 8 & 2201 & 182199 & 43751 & 1820 \\
\hline 9 & 2201 & 238681 & 45501 & 1892 \\
\hline 10 & 2201 & 312673 & 47321 & 17744 \\
\hline Всього & 20834 & - & & \\
\hline
\end{tabular}

Джерело: розрахунки автора.

3 наведених розрахунків видно що здача земель в оренду є значно вигідніша.

Висновки. Проведене дослідження стосовно передбачення ціни земель сільськогосподарського призначення дає підстави стверджувати про нагальну необхідність визначення рівня таких цін ще до відкриття ринку земель, що зумовить ефективне функціонування ринку земель сільськогосподарського призначення.

1. Питання щодо вибору моделі ринкового обігу земель сільськогосподарського призначення в Україні доцільно розглядати системно та в комплексі із забезпеченням збалансованого розвитку сільського господарства й сільських теріторіальних громад, збільшення доданої вартості на сільських територіях, збереження існуючих та створення нових робочих місць в аграрному секторі та інших видах зайнятості в сільській місцевості, підвищення іiї інвестиційної привабливості тощо. Це зумовлює необхідність розроблення й уведення політики регулювання земельних ринків (прав власності, оренди й акціонерного капіталу), з тим, щоб створити основу для майбутнього зростання, що досягається через підтримання тих типів господарств, які відповідатимуть інтересам села i країни.

2. Досвід країн СС переконливо доводить, що без уведення спеціальних регуляторних заходів, на купівлю-продаж земель сільськогосподарського призначення унеможливить збалансований 
розвиток українського сільського господарства. Без ефективних і дієвих механізмів малі і середні виробники можуть залишитися за межами ринку сільськогосподарських земель.

3. Враховуючи що значна частина земельних паїв нині знаходиться в оренді необхідно запровадити постійний моніторинг використання земель та враховувати усі функції екосистеми i, насамперед ті, що мають загальносуспільне значення та довготривалий характер, а не лише функцію максимізації виробництва біомаси у короткостроковій перспективі.

4. Невід'ємною умовою формування цивілізованих та прозорих земельних відносин $є$ подолання корупції та протидії земельному, майновому й аграрному рейдерству, втілення дієвих механізмів забезпечення захисту прав власності й користування на земельні ділянки, забезпечення прозорості земельних трансакцій, що вимагає комплексної, злагодженої й цілеспрямованої роботи органів виконавчої влади та місцевого самоврядування.

5. В законі «Про консолідацію земель» чітко прописати положення щодо захисту малих і середніх товаровиробників.

\section{Джерела та література}

1. Земельний КодексУкраїни

2. Постанова Кабінету Міністрів України від 17.11.1997 № 1279.

3. Статистичний збірник. Сільське господарство України [Електронний ресурс]. Державна служба статистики України. 2018. Режим доступу : www.ukrstat.gov.ua > druk > publicat > kat_u > 2019

4. Ходаківська О. В. Екологізація аграрного виробництва : монографія. Київ : ННЦ «IAЕ», 2015. 350 с.

5. Шворак А. М. Природні кормові вгіддя та соціально- економічний розвиток сільських територій. Економічний часопис Східноєвропейського наиіонального університету імені Лесі Украӥнки: журнал. Луцьк : Вежа-Друк, 2018. № 2 (14). С. 112 - 116.

6. Шпичак О. М. Сільське господарство України на початку та в кінці XX століття. Київ: IAE, 2000. 68 с.

7. Шпичак О. М. Методологічні підходи щодо реалістичної оцінки результативності трансформаційних перетворень у вченні академіка I. І. Лукінова. Трансформаційні перетворення в аграрній сфері України за вченням академіка I. І. Лукінова та їх втілення в сучасні умови господарювання: зб. наук. праць за матеріалами теорет. семінару 15 грудня 2016 р. Київ: ННЦ «IAЕ», 2017. С. 5-14.

8. Israel Land Authority. Israel. URL : http://land.gov.il/ en/Pages/AboutUs.aspx.

9. Bodenverwertungs- und -verwaltungs $\mathrm{GmbH}$ - (BVVG). Germany. 1992. URL : https://www.bvvg.de/INTERNET/ internet.nsf/HTMLST/UNTERNEHMEN.

10. Krajowy ośrodek wsparcia rolnictwa (KOWR) - National Center for Agricultural Support. Poland. 2017. URL : http://www.kowr.gov.pl/ukur.

11. Agenţiei Domeniilor Statului (ADS) - The State Domain Agency. Romania. URL : http://www.domeniilestatului.ro/.

12. U.S. Department of Agriculture (USDA). USA. URL : https://www.usda.gov/our-agency/about-usda. 13. Evi CXXII. törvény a mezö- és erdőgazdasági földek forgalmáról. A magyar parlament. Budapest. 2013. URL : https://goo.gl/5pA4r2.

14. Státního pozemkového úr̆ad (SPU - State Land Office) of Czech Republic. URL : https://www.spucr.cz/statnipozemkovy-urad/o-uradu.

15. Land Development and Rural Settlement Society (SAFER). France. 1960. URL : https://www.safer.fr/lessafer/quest-ce-quune-safer/.

16. Japan's Law on Agricultural Committee № 88. The Parliament of Japan (Kokkai). 1952. URL : https://goo.gl/nMVfky.

\section{References}

1. Land Code [In Ukrainian].

2. Resolution of the Cabinet of Ministers of Ukraine from 17.11.1997 № 1279. [In Ukrainian].

3. Statistic collection. Agriculture of Ukraine. (Electronic resource)/State statistics service of Ukraine. - 2018. Mode of admission: www.ukrstat.gov.ua > druk > publicat > kat_u > 2019 [In Ukrainian].

4. Khodakivska, O.V. (2015). Ekolohizatsiia ahpapnoho vypobnytstva [Ecologization of agrarian production]. Kyiv: NNTs "IAE" [In Ukrainian].

5.Shvorak A.M. Natural feed grounds and social-economic development of rural territories. Economic Journal of East European National University named after Lesia Ukrainka: Journal/ Lutsk: Vezha-Druk, 2018. №2(14). Page 112-116. [In Ukrainian]. 
6. Shpychak, O.M. (2000). Silske hospodarstvo Ukrainy na pochatku ta v kintsi XX stolittia [Agriculture of Ukraine at the beginning and end of the twentieth century]. Kyiv: IAE [In Ukrainian].

7. Shpychak, O.M. (2017). Metodolohichni pidkhody shchodo realistychnoi otsinky rezultatyvnosti transformatsiinykh peretvoren $\mathrm{u}$ vchenni akademika I.I. Lukinova [Methodological approaches to the realistic assessment of the effectiveness of transformational transformations in the teaching of academician I.I. Lukinov] Transformatsiini peretvorennia $\mathrm{v}$ ahrarnii sferi Ukrainy za vchenniam akademika I.I. Lukinova ta yikh vtilennia $\mathrm{v}$ suchasni umovy hospodariuvannia: zbirnyk naukovykh prats za materialamy teoretychnoho seminaru. (pp. 5- 14). Kyiv: NNTs "IAE” [In Ukrainian].

8. Israel Land Authority. Israel. URL : http://land.gov.il/ en/Pages/AboutUs.aspx. [In English].

9. Bodenverwertungs- und -verwaltungs GmbH - (BVVG). Germany. 1992. URL : https://www.bvvg.de/INTERNET/ internet.nsf/HTMLST/UNTERNEHMEN. [In English].

10. Krajowy ośrodek wsparcia rolnictwa (KOWR) - National Center for Agricultural Support. Poland. 2017. URL : http://www.kowr.gov.pl/ukur. [In English].

11. Agenţiei Domeniilor Statului (ADS) - The State Domain Agency. Romania. URL : http://www.domeniilestatului.ro/. [In English].

12. U.S. Department of Agriculture (USDA). USA. URL : https://www.usda.gov/our-agency/about-usda. 13. Evi CXXII. törvény a mező- és erdőgazdasági földek forgalmáról. A magyar parlament. Budapest. 2013. URL : https://goo.gl/5pA4r2. [In English].

14. Státního pozemkového úřad (SPU - State Land Office) of Czech Republic. URL : https://www.spucr.cz/statnipozemkovy-urad/o-uradu. [In English].

15. Land Development and Rural Settlement Society (SAFER). France. 1960. URL : https://www.safer.fr/lessafer/quest-ce-quune-safer/. [In English].

16. Japan's Law on Agricultural Committee № 88. The Parliament of Japan (Kokkai). 1952. URL : https://goo.gl/nMVfky. [In English]. 